\title{
EQUATORIAL GUINEAN MIGRANTS IN SPAIN. AN ANALYSIS OF IMPLICIT DISCOURSE
}

\author{
Catalina Iliescu Gheorghiu \\ University of Alicante (Spain)
}

Rather than making a theoretical point, this paper intends to provide support for an analysis model of implicitness in non-fictional, non-professional discourse. By applying it to self-narrations of life-stories, I hope to demonstrate not only its methodological viability for this type of discourse (almost monological, highly emotional and requiring a special trust with the interviewer) and in this particular case of Equatoguinean emixiles in Spain, but also its efficacy as a tool for Postcolonial Studies which researchers might apply to the discourse of migrants from former colonies who settled after independence in the metropolis. Such may be the case of Indians and Pakistanis in UK, or Algerians in France, who manage invisibility or empowerment issues. This methodological tool might help researchers better to understand non-verbalized problems that migrants face between their present and their past.

\section{Aims, Hypothesis, Corpus and Methodology}

In this study I will approach the four dimensions of implicit discourse as they manifest in the self-narrations of six Equatoguineans living in Spain (Alicante) who belong to the four main ethnic minorities: the Fang (originally from the mainland region, organized in clans by common ancestor lineage and traditionally ruled by chieftains, whose language is Fang), the Bubi (territorially bound, organized in clans and by common ancestor lineage, whose relations are 
traditionally based on chieftaincies and kingdoms and whose language is Bubi, although nowadays they speak Pichi), the Anobonese (descendants from slaves settled on the island of Anobon on the way to America, whose language is Fâ d'ambo and whose organisation has no clan subdivisions), and the Ndowe (from the mainland coastal region, who speak Ndowe and preserve their organization in clans and by common ancestor lineage). As Aixelà shows (Equatorial Guinean 51), there are other two minorities: the Bisio (who maintain a clan organization on territory that is not clearly defined) and the Fernandinos, originally from Sierra Leona and Ghana (brought by the British to the island of Bioko to work the plantations where they mixed with descendants of freed slaves from Liberia), whose language is English and are of the Protestant faith, unlike the rest of the groups who combine Catholicism and ancestral rite. This variety of identities plays a crucial role in the shaping of the Equatoguinean diaspora and cross-border activism, and is reflected in my interviewees’ stances and discourse. Although implicitness has been considered by pragmalinguists in the last two decades (with insights into literary, journalistic, specialized discourse), Ruiz Ruiz innovatively applies it to social discourse because, as he claims, "all social discourse contains implicit elements" (173). Following in his footsteps, I intend to investigate implicitness in Equatoguinean migrants' life-stories. First because the theoretical framework provided by pragmalinguistics and Gricean conversational maxims in general and by the four-dimension model of implicitness in particular, seems to be an appropriate grid of analysis for this "delving into traumas" type of discourse and can open a line of interdisciplinary research. Secondly, because this theoretical framework has been applied to discourse analysis mainly in fiction (narrative, drama) or situational communication (specialised/professional interaction) but less to the self-narration of exile (except perhaps for war victims or asylum interviews). The premise of this investigation is that discourse is 
sufficiently resourceful to allow a speaker to conceal or insinuate whenever (s)he cannot/does not want to be explicit and I will provide some empirical data to support this idea. My hypothesis is that my interviewees' choice for implicit discourse is often related to exile, totalitarianism and fear of both direct reprisals (against their activism or militancy) and indirect reprisals (against relatives inside the country) and that the two intentional dimensions of implicitness are more frequently used than the unintentional ones.

The empirical material I analysed was extracted from the transcript of six guided in-depth interviews (several sessions of between one and three hours) with Equatoguinean residents in the region of Alicante (Spain), who narrated their migration/exile life-stories. The interview contained 113 questions divided into three sections: family and childhood; youth and studies; social network and exile.

Implicitness lay both at the individual level, when they recalled personal experiences, feelings and convictions, and at the collective level when they observed, diagnosed, criticized what they regarded as harmful/threatening circumstances.

Although examples of implicit discourse were extracted from the whole interview, the third section seemed to provide more such utterances initially selected for my corpus (a number of 73). After a first screening, 20 were discarded because of their low degree of implicitness and the others were analysed within the four dimensions described by Ruiz Ruiz as: (a) insinuated, the information expressed implicitly and intentionally (21 samples); (b) concealed, the information which is not expressed but is in fact able to generate some degree of implicitness (17 samples); (c) underlying, the information implicitly expressed, not intended, but not unintended either (8 samples); (d) failed, unwillingly and unintentionally expressed information (7 samples). The first two dimensions have a common feature: intentionality. Both are characterized by the 
speaker's reluctance to be explicit: one insinuates by saying, the other by not saying. The other two dimensions are based on hesitation (underlying) and on betrayal by their subconscious (failed), therefore, intentionality is low or absent. My interviewees, while perfectly able to give explicit accounts of certain facts (accurate command of Spanish, trust in the interviewer, no time pressure), when tackling the third section of the interview (exile) chose not to do so. One of my research questions is why this happens. Do all the interviewees resort to implicitness? And if so, are its four dimensions equally distributed? Apparently, my six informants (regardless of the ethnic group to which they belong, including the ruling one in Equatorial Guinea) resort to implicit discourse and they seem to prefer its insinuated and concealed dimension. One possible reason might be the coercive power they feel the regime exerts in their homeland. My hypothesis is that in this type of self-narration, (provided conditions of extended length of the interview and trust between speakers and interviewer are met) the four-dimension model of analysis proposed by Ruiz Ruiz helps to identify and understand reluctance, hesitations and non-verbalised assumptions that remain implicit in the emixiles' discourse. He explains (186) that the analysis comprising detection and interpretation of implicitness must consider texts in their integrity, since "implicit discourse can only be detected by inference from explicit discourse and nonverbal elements”. Although I acknowledge their relevance, I will not analyse the latter (kinesics, proxemics, gestures) in my six interviewees' speech, nor the paralinguistic elements (pauses, false beginnings, sighs, hesitations) which deserve to be per se the object of a further study. I will focus only on verbal language, namely on the four dimensions of implicit discourse, a device they use whenever they wish to describe the motives for their departure from Guinea and their remaining in Spain, their condition as expatriates, or when criticizing either the current situation in EG or the stances taken by Spanish society towards them/their country. 


\section{Theoretical Background}

One decade after Ducrot had published his “Theory of implicitness”, Jaworski proposed an interdisciplinary attempt to combine linguistics, ethnography of communication, pragmatics, hermeneutics and ideology in response to such warnings as Hall, Sarangi and Slembrouck’s (181) on "the neglect of silence in linguistic analysis"1. There is a wide range of discursive instances (professional, family conversation, ritual talk, literary or other forms of artistic communication) in which silence is seen not only as an acoustic signal (pause), non-verbal category or rhetoric ellipsis, but in a broader sense, as suppression of certain voices or perspectives from a narrative analysis point of view. In this broader acceptation, silence can be scrutinized together with a number of interactions in which it intervenes: refusals, unanswered questions, whispers, or avoidance of a topic, which, although they are not "silence” stricto sensu, can be considered as discursive mechanisms producing the same effects and thus, analysable under this category. Javorski (3) introduces the idea of "silence as metaphor for communication”, showing that the meaning of silence is more ambiguous than that of speech, more "contextdepending” (4).

Starting from the findings of Van Dijk and Fairclough, in her approach to discourses of silenced/coded language, Ruth Wodak analyses the insinuations contained in the "coded language” employed by Jörg Haider in his electoral speeches. She defines allusions as associations which are only hinted at, while the task of making them explicit during the act of reception belongs to listeners/viewers/readers (212). She also shows that allusions depend on “shared knowledge” (Searle’s background assumptions, Sperber and Wilson’s mutual manifestness, van Dijk’s common sense knowledge). When alluding to something, the speaker counts on the audience's general preparedness for resonance, that is, the hearers' tendency to 
expand literal meaning according to shared knowledge. Scholars such as White (17) argue that the implied appraisal poses major problems because activations of meanings rely on implications, inference and associations, i.e. they rely on the reader/listener to interpret the depicted state of affairs as positive or negative according to the value system they bring to the text. More recent approaches in linguistics (Asher) revisit implicatures (including Carston's or Recanati's approaches to inference at the confluence of semantics and pragmatics) in order to open the utterance spectrum to the concept of discourse relations and to envisage interpretation of larger texts through theories such as the "Segmented Discourse Representation” (Asher and Lascarides) which Irmer related to frames (as stereotypical scenarios) in an attempt to expand the object of analysis from expressed language into thought and vital experience. Escandell-Vidal shows that recent pragmatics focuses on revisions or refinements of Gricean maxims, see Horn on the quality maxim, or Levinson on default interpretations, who suggests that there is a third layer between the sentence’s and the speaker’s meaning, namely the “utterance-type meaning”, depending not on context, but on normal use of language. The relation implicitness-explicitness has been applied by Kisielewska-Krysiuk to lying (violation of the Gricean quality maxim) already studied in philosophy, ethics, sociology but perhaps with fewer linguistic accounts. She distinguishes between "saying a falsehood” and "falsely implicating” and claims that honesty of speakers and reliability of testimonies seem to be “an effect of hearers’ epistemic vigilance”. This type of analysis can also be applied to social discourse, for instance in the case of interviews with asylum seekers. In my informants’ narrations of their exile, I did not identify either examples of "falsehood”, or of "falsely implicated meanings" since this type of discourse is based on the presumption of truthfulness. However, to avoid breaching what we know as Grice’s 
quality maxim, speakers resorted either to silence, with its afore-mentioned mechanisms, or to implicitness in its four dimensions:

1. The insinuated dimension (information intentionally included but not openly stated which can be detected through speech clues, or non-verbal elements). In the words of Ruiz Ruiz (175), this is the closest dimension to explicitness, since the speaker leaves traces so that the hearer can infer insinuations from explicit discourse. This process depends on "multiple factors related to the speaker (strategic ones, linked to communicative ability), to the receiver (for example capacity to process information, sensitivity and attention) or even to the context”. Its intention is to disguise certain contents and, as it uses specific codes, it does not reach all of its potential recipients. At other times, it is used to improve persuasive efficiency of messages or to condense meanings. The example offered by this author is the $15 \mathrm{M}$ Spanish movement’s slogan: "we are not merchandise in the hands of politicians and bankers" which insinuates that citizens are in fact treated as commodities. Elliptic antithesis and creative metaphors are the most common tropes associated with insinuation.

2. The concealed dimension (information which is intentionally silenced or hidden) refers to those non-uttered words/phrases/sentences, which by their absence produce an insinuation, the decoding of which depends on the receiver whose responsibility is increased. In the view of Ruiz Ruiz, it is more difficult for this kind of message to produce the semantic effect intended by the speaker. From the analyst's perspective, the difficulty resides in imputing the speaker the intention of those unuttered parts. From this perspective, the hidden discourse might not be seen by some scholars as belonging to implicit discourse since it cannot be inferred from the explicit one. According to Van Dijk (62), the concealed discourse is deemphasized by means of euphemisms, vague expressions, implicitness, whenever it is used 
for purposes of ideological manipulation (see for instance the minimization of civilian killings described as "collateral damage" in the attack on Iraq in 2003 by the US and its allies). Other scholars refer to this dimension as “discursive exclusion” (Herzog qtd. in Ruiz Ruiz 180), present in those mass-media reports in which any positive references to topics such as immigration are omitted in order to underline its negative aspects. The example he uses is the metaphor of the immigrant as an "ungrateful guest", a metaphor which intentionally hides the revenues from taxes paid by this segment. In other cases, the hidden discourse is the result of a strategy of caution, when "certain delicate topics or contents are avoided, depending on the context in which the discourse is produced" (180). For instance, by calling a terrorist organization "a group of assassins”, its political intentions are hidden and by referring to it as a "revolutionary group" the criminal nature of its actions is silenced. At other times, the aim of this concealed speech is courtesy or prudence. Ruiz Ruiz shows that concealment has a greater argumentative efficiency than negation because one has to defend what one negates whereas what one hides, goes unnoticed. The concealed dimension is often associated with an asymmetric power relationship. Concealment is also a resistance strategy for lower classes regarding public discourse. They simulate conformism in order to prevent detection by those in power.

3. The failed or unintended dimension (information not meant to be conveyed but implicitly and unwillingly contained in the utterance) has been considered, from the field of psychoanalysis, as a dimension emerging precisely from a failed concealment strategy, i.e. information the speaker reveals implicitly and unintentionally, somehow betrayed by his/her own words. The failed discourse is related to the "group conscience" and encloses behaviours unaccepted or censored by society, since it paradoxically emerges from the individual's wish to conceal 
something likely to have a negative assessment or consequence. This type of speech often resorts, not to direct knowledge (by experience), or to indirect knowledge (by reference) but rather to imaginary knowledge (by supposition) in its attempt to hide a lack of knowledge or offensive assumption.

4. The underlying dimension (information not clearly meant for transmission since the speaker may or may not have intended to say it) often resorts to conventional metaphors. Unlike new, fresh, creative, surprising metaphors, which characterize the insinuated discourse, evoking and persuading by means of cognitive effects and making the receiver identify with the message, the conventional metaphor tends to go unnoticed, and thus generates many more underlying and implicit discourses. The differentiation might be symmetrical to Ricoeur’s famous distinction between dead and living metaphors. In terms of Ruiz Ruiz (184), this is "the most implicit dimension of discourse” since it often goes unnoticed by both speaker and receiver. The example he offers is the common expression describing access to employment in Andalusia: “[go there] for them to give you a job”, responding to the logic of the gift, in which a bond of gratitude is implied.

The first two categories (intended dimensions) are related mostly to speakers intentions, whereas the latter two (unintended or not clearly intended) are linked to symptoms and attitudes which are a reflection of social representations.

\section{Sociohistorical Background}

A Sub-Saharan country in the Bight of Biafra, on the central west coast, with a surface area of 28,017 km², Equatorial Guinea (EG) is divided into two provinces: (1) Río Muni (26,000 $\mathrm{km}^{2}$ ) comprising a continental strip between Cameroon and Gabon and the Islands of Corisco, Elobey Grande, Elobey Chico; and (2) Bioko (formerly Fernando Poo) (2,051 km²) comprising 
the islands of Bioko, Annobon and several adjacent islets. Prior to the twentieth century, as Ugarte shows (22), the colony was the victim of Spanish administrative neglect. Nevertheless, after the so-called disaster of 1898 (and the definitive end of Spanish colonial control of Latin America), Spain turned to Africa to recover prestige and to "establish renewed interest in the continuation of its colonizing past with the Patronato de Indígenas". Today, there is no doubt that development in the metropolis was in part due to despoliations which had devastating consequences on EG's physical and geographical environment. The Spanish colonial system followed an “assimilationist” policy, also called Hispanic (Ki-Zerbo 728) since it had been previously used on the American continent. This model spread mistrust among the different ethnic groups and often gave them labels which resulted in harmful stereotypes. In the 1940s and 1950s the Francoist regime exerted control through the Bureau of Moroccan and Colonial Affairs and in spite of the regime's paternalistic policies, there were improvements in health, education ${ }^{2}$ (see example $1 \mathrm{~h}$ in my analysis) and agricultural initiatives which boosted exports. In response to anti-colonialist pressure, EG was granted autonomous status in 1965. The advent of independence in 1968 gave way to a brutal dictatorship (unfortunately, not an atypical pattern in postcolonial Africa) led by Francisco Macías Ngnema (1970-79).

Postcolonial Equatorial Guinea

Described by Liniger-Goumaz as “Afro-fascism”, the dictatorial regime led by Francisco Macías Ngnema perpetrated mass killings on a scale matching the cruelty of those associated with Mobutu Sese Seko in Zaire, Idi Amin in Uganda or Ahmadou Ahidjo in Cameroon. Ugarte (25) describes how, by 1972, Macías:

Had taken complete control of the government, outlawed all political parties except one (PUNT - Partido Único Nacional de Trabajadores) and assumed the 
title of president for life, imitating and in many ways going beyond Franco in his obsession with power. The Macías government was responsible for statesponsored terror: mass executions, the exit of up to one-third of the entire population, imprisonment of thousands of citizens, pilferage, ignorance, and neglect of rising malnutrition and infirmity that many citizens were forced to endure.

The harsh dictatorship produced mass exile and imposed silence on intellectuals and writers, all opposition was stifled (Ndongo-Bidyogo), and infrastructures (electrical power, roads, water distribution) and services (education, health-care, transportation) fell into ruin. This gave rise to a coup led by Macías’ own nephew, Teodoro Obiang, a high official declared by his uncle a disloyal citizen. Obiang claimed he supported democratic change, but his new regime (1979-present) soon turned out to be as oppressive as his uncle's and a new wave of exile began. Opponents and critics were imprisoned, tortured and executed (see examples 1a; 2c; 2b in my analysis). The economy meanwhile was opened to Europe and the West, bringing profits which were not re-invested in much needed domestic improvements, but instead served to increase the Mongomo Clan's assets and those of his restricted circle (see example 1g). The system's paradox is summarized by Okenve (4) in his diagnosis: "a weak and yet an omnipresent state” (see example 1e). The discovery of oil in the 1990s led to a return of the First World to EG; in terms of per capita income it ranks 131 on the Human Development Index, while its GDP has increased sevenfold in recent times (see examples 4a; $4 \mathrm{~d}$ in my analysis). Its soil and marine platforms produce 300,000 barrels a day of high quality and easily, safely extractable oil, which make analysts talk of "the African Kuwait”, or the new "El Dorado" (Denantes; Campos). 
The lack of freedom, transparency and redistribution of natural resources, has caused frustration among an Equatoguinean society which has lived for almost half a century in silence, discontent and fear, and sees exile as the only survival alternative. Aixelà explains (Guinea Ecuatorial 147) that the low profile of diasporic activism and networking might be a result of Equatoguineans' lack of tradition in associative networks, and of their fear of the regime's tentacles (e.g. censorship exerted by consulates, see example 1f). Another reason might be the mutual suspicion among ethnic groups, especially against the predominant one (see examples 2a; 3c). However, with the development of IT, Equatoguinean residents in Spain are now increasingly connected and updated. Vertovec (3) defined this dual activism (geographically distant but politically homeland-oriented) as transnationalism.

\section{Equatoguinean Migration to Spain}

According to Ondo, Bokesa and Liniger-Goumaz (107), there are now about 200,000 Equatoguineans living abroad. Apart from an early exile migration made up of opponents of colonialism, which was later transformed into an exodus caused by the two dictatorships, there was an educational migration of people whose aim was to complete their university studies in Spain. The Equatoguinean Education Law (2007) introduced free and compulsory education until the age of 16, but access to higher education as well as centres, resources, technology is still scarce (see example 1b). Having qualified, students would, in theory, return home and invest the acquired knowledge in improving conditions. However, very few of them actually did return. A third type was labour migration motivated by a desire to improve living standards. This had two stages: to Spain and neighbouring African countries (1968 - late nineties), and towards EG after the discovery of oil. The protagonists of the latter are the second diasporic generation. 
According to the INE (National Statistics Institute), in July 2013, there were 19,677 people born in EG living in Spain, of whom 7,625 were men and 1,205 women, but figures do not comprise members of the Equatoguinean community who have Spanish nationality. The Statistics Department of the Alicante Town Hall released the following numbers: of the 332,067 residents of Alicante, there were 381 Equatoguinean residents in 2012 (138 men and 243 women) and 360 in 2013 (139 men and 221 women). Although there is a decrease, it does not appear to be as significant as we might have expected given the oil boom which was supposed to bring back emigrants and prosperity. The reason for the reluctance to return appears to be the fear spread by the dictatorial regime. This conclusion was reached by Iliescu and Bosaho (217) who studied the relationship between the Equatoguinean diaspora's motives for migrating and their reluctance to return. In turn, Aixelà (Equatorial Guinean 16) shows that fear of the dictatorship prevented early migrants from ever returning to visit their families until the mid1990s and "the reluctance of those born abroad to travel back to Equatorial Guinea until the political situation changes has been a constant factor".

The Concept of "Emixile"

Within the current debate on populations on the move, an interesting distinction is drawn by Ugarte (10) between exile and migration. Other authors had already highlighted the connotation of individuality and of private life implied by exile, while emigration/immigration seems to affect rather the public realm and a collective dimension of human existence. But Ugarte shows that exile and migration have at least two aspects in common: both concepts presuppose an experience of separation, of departure from a homeland and both involve reception in a new country, which inevitably affects the relationship between the self and the other. What differentiates them is perhaps the divided self which characterizes exile, or in 
Ugarte’s terms, a split identity together with "competing senses of belonging, heightened awareness of justice and the ethical and ostracism" as well as a certain historical dimension. While migration remains within the social or sociological framework, tackling demographic, statistical processes and raising interest from a synchronic point of view, exile is perceived as more diachronic, literary and political. Based on this conceptual premise, Ugarte proposes his own notion of emixile a combination of the term "exile”, from the Latin exilium (banishment or last resort in hostile political circumstances), and the term "migrant" coming from emigrare, to depart, which implies a willing departure envisaging a perceived gain, usually a material one. Ugarte (2) argues that both terms overlap in this new world with blurred borders, which globalizes dissidence and makes people flee from oppression.

The emixile condition of the interviewees results from a departure that can be regarded either as migration (for economic or academic reasons) or as exile (for political reasons) and from a no-return option based on fear which clearly shares the features of exile.

As I said above, this paper deals with implicitness in self-narrations of Equatoguinean emixiles in Spain. In what follows I analyse some examples of implicitness extracted from their narrative in order to determine whether speakers opt for implicitness or not, and if they do, which of its dimensions are more recurrent and why.

\section{Sample Analysis}

The empirical corpus for this study consists of the transcription of six guided in-depth interviews $^{3}$ with Equatoguinean residents ${ }^{4}$ in Alicante (Spain). The variables considered for selection of participants were: sex, age, social status, and ethnical origin (they belong to the main four groups: Bubi, Fang, Annobonese, and Ndowe). The names I use to refer to them are 
fictitious ${ }^{5}$. For reasons of length I will discuss only the most relevant utterances of the total number of implicit discourse examples (53).

The Insinuated Dimension (21 samples found in my corpus)

To this category, Ruiz Ruiz assigns those utterances containing information intentionally included but not openly stated, which can be detected through speech clues or non-verbal elements. The six interviewees provided many examples of such utterances in their narrations. Jesús

1a. 'Aquí estoy mejor que en Guinea. Aquí me respetan, hay democracia.' En España se vive mejor que en la mayoría de países europeos (Here I feel better than in Guinea. Here I am respected, it is a democracy. One lives better in Spain than in most European countries) ${ }^{6}$.

This is part of his answer when asked about his motives for migrating. Obviously, the insinuated message is that there is no respect for him in his country. He does not say it explicitly but he implies it intentionally. The fact that he belongs to the ethnic group in power (Fang) does not provide status in his case. In fact, Jesús confesses he had to leave Equatorial Guinea because of the lack of security and freedom. The insinuated dimension is structured on the antithesis here-there, and on the use of affirmatives to imply negation, an avoidance strategy to elude a sentence such as "in my country I am not respected".

Jorge

1b. [What advice would you give your descendants?] 'Educación. Con estudios no te pueden apartar.' Que se cultiven. Así, por mucho que quieran apartarlos, el escalón donde quieran bajarlos no será tanto. (Education. If you have qualifications, they can’t push you aside. Let them learn. This way, 
no matter how hard others try to push them aside, the rung assigned to them will not be so low).

This utterance hints at the fact that the normal tendency is to exclude opponents and citizens not affiliated to the regime's cause. Education is underdeveloped and selective in EG (see note 1) and if studies are essential for each nation, for Equatoguineans they are a vital escape route from poverty and protection from arbitrary decisions and discrimination on grounds of ethnic origin and loyalty to the ruling party of which the six interviewees complain throughout their narrations. The insinuated meaning is that having qualifications is the exception, not the rule for certain segments of society and that being pushed aside is not uncommon.

Rita

1c. [Is orality important?] 'Tú sabes qué fincas te corresponden, pero hasta que tu familia no te lo dice, no es válido.' Las tradiciones se transmiten verbalmente. Tus padres te dicen cuándo te independizas. El plano verbal es fundamental. Somos una cultura oral. (You know which land is yours, but nothing is valid until your family tells you. Traditions are transmitted verbally. Your parents tell you when you start life on your own. The verbal level is fundamental. We are an oral culture).

The implicit information in the highlighted sentence (confirmed by the whole reply) is the importance of orality in African cultures: inheritance, coming of age, or matrimony are performed through words, reminding us of Austin's differentiation between performative speech acts and the perlocutionary force they contain. While the implicit performative act depends on paralinguistic/kinesic cues and the power relation between interlocutors, the explicit one actually performs an action with an effect because the speaker and the hearer share linguistic conventions 
which dictate that to utter certain words in certain circumstances counts as performing a certain act with a certain effect. In this case, an utterance such as "I give you this land" would be equivalent to a notarized transfer.

1d. [Does having dual citizenship ${ }^{7}$ help?] Se es español de papel. (You're a paper Spanish citizen).

According to Vertovec (94), migrants' interest in the political plight of their place of origin and the ability to act are heightened nowadays "due to advances in communication, cheapness of transport and policy shifts such as the extension of dual citizenship/nationality”. In her utterance, my interviewee shows her disappointment towards a measure which formally appears to give the former colony equal status with the metropolis but in practice does not. Her criticism is insinuated through this figure of style creating a poetic effect. The metaphor "español de papel” (which some other interviewees refer to as "español de segunda" - second class Spaniard), in opposition to "a true Spaniard" is chosen by Rita to avoid directly accusing her host country of hypocrisy, although she does so implicitly, so as to avoid an FTA (face threatening act in Levinson's terms).

1e. [Have you ever had to militate?] 'Me han militado.' (equivalent to he sido militada, I was “militated”). Como funcionaria, me obligaban a cotizar en el partido del poder. (As a civil servant, I was obliged to pay contributions to the party in power).

We deal with a term, to militate, which my interviewee creatively modifies through derivation, by changing the aspect of grammatical category. She replaces the active proper use in Spanish with a passive voice: to militate (from Latin militāre) in its third DRAE acceptation, "figurar en un partido político o en una colectividad” (be member of a political party or an 
assembly) is unexpectedly used as ser militado (to be militated). The subtlety and irony of the expression raises its degree of implicitness. The insinuated information is the obligation of any Equatoguinean civil servant to register with the party in power and pay a membership fee. The same question is differently answered by Jesús (Fang ethnic group). He says: "I was affiliated to the party in power. It was compulsory. I did not militate”. He needs to exonerate himself because he is Fang. Later he adds: "Unos son radicales, no respetan ni a los suyos/Some Fang are radicals, they have no respect, not even for their own people”. This could be an example of the failed dimension of implicit discourse that reveals information the speaker did not mean to give. In this case, he implies that disrespect is common towards other groups but surprising towards Fang. The use of the impersonal pronoun unos (some) and the third person (the subject never includes himself) is relevant and suggests a certain mechanism of estrangement (the speaker is on the side of the victims, not of those in power).

Juan

1f. [What is your opinion about Guinean associations in the diaspora?] en algunas partes funcionan bien. (In some places they work well).

The insinuated information my interviewee provides through this sentence is that associations do not meet their aims in Spain. Vertovec (78) shows that transnational practices among immigrants are highly diverse between and within groups (whether defined by country of origin, ethnicity, immigration category or any other criteria). Former UN Secretary-General Kofi Annan emphasized the importance of recognizing that migrants can "maintain transnational lives” (158). “Transnationally, the politics of homeland can take a variety of forms: exile groups organizing themselves for return, groups lobbying on behalf of a homeland, external offices of political parties, migrant hometown associations, and opposition groups campaigning or planning 
actions to effect political change in the homeland” (95). However, in this case we may infer that Juan does not seem to trust them.

1g. [Will those who go back to Equatorial Guinea after the discovery of oil have a better future?] Muchos están viviendo mejor. Se acomodan al sistema y al régimen. Crean una casta aparte. (Many are living better. They adapt to the system and to the regime. They create a special caste).

This is an interesting example of viewpoint shift. While the question refers to the future, the answer is anchored in the present. The speaker does not want to forecast. He relies on data known to him. In spite of its affirmative appearance, the answer is in fact negative, although not explicitly stated by Juan but rather insinuated: those who manage to live better do so in virtue of their belonging to a new special caste, not because the conditions in the country have improved.

\section{Viviana}

1h. [Were your parents and grand-parents educated?] 'Mi madre, ya de casada, quería ser maestra y su padre no la dejó porque iba a viajar mucho.’ Mis abuelos, los cuatro, sabían leer y escribir. (My mother, when she was married, wanted to be a teacher, and her father wouldn't let her because she would have to travel a lot. My grand-parents, the four of them could read and write).

In this utterance, we find several implicit data. First, the male power (father, husband) exerted over women; secondly, the fact that being a teacher at that time implied travelling a lot, and thirdly, that in this African society as in some western ones, the primordial task of a woman (even an educated one) was to take care of her family. The insinuated meaning is that a father, prior to a husband, can control his daughter's decisions. The three inferences are clear to any 
Equatoguinean of a certain age in virtue of shared knowledge. However, Viviana introduces clues for the interviewer (as outsider); for instance, the explicit causal adverbial subordinate (porque iba a viajar mucho) to make clear that this profession supposed travelling from town to town.

The Concealed Dimension (17 samples found in my corpus)

This highly context-dependent category refers to information that can be intentionally silenced or hidden, not on semantic or aesthetical grounds, but rather to elude repression, to avoid offence or to save face. Thus, this dimension is tightly bound to power and discursive silence. As I said above, the fact that it falls into the category of implicit discourse is arguable, since it is not inferable from the explicit one, unlike the other three dimensions (insinuated, failed and underlying).

Jesús

2a. [Do you relate to the rest of ethnic groups equally?] Igualísimo. Tengo más no-fang que fang. Aparte de fang, me relaciono con bubis. Somos como hermanos. Estuve a punto de casarme con una mujer bubi. (Extremely equally. I am more non-Fang than Fang. Apart from Fang, I relate to Bubi. We are like brothers. I was about to marry a Bubi woman).

This is a message illustrating both the concealed and insinuated dimensions: "igualísimo" is an invented superlative comparison degree not applicable to such notions as equal, hence the humorous effect meant to divert the interviewer's attention from the question which is answered by means of a hyperbole meant to hide the unpopularity that some Fang have gained for themselves. In order to be more convincing, he adds further information on this delicate point. As a member of the ethnic group in power, he is aware of the peril of extended antipathy and he 
resorts to humour and exaggeration. Then he introduces an insinuated sentence which suggests that: a) a Fang is not expected to relate to the rest of the ethnic groups, a perception which is implicit in other informants’ narrations (see example 3c), b) he might feel ashamed of the behaviour of the Fang in power (see Liniger-Goumaz 14-15; Ondo, Bokesa and Liniger Goumaz 107, on the persecutions, killings and tortures led by the ruling clan), unlike the interviewed Bubi who feel proud of their ethnic roots and define their identity as Bubi first, and Equatoguinean second. Through the information provided in the extended reply, Jesús proves that in fact, he does not relate to each group equally, as he states, since he underlines his good relations with $\mathrm{Bubi}^{8}$. His claim of friendship with precisely this group reinforces the concealed dimension of the first part of this example.

Jorge

2b. [Did the political climate in Equatorial Guinea have an influence on your exile in Spain?] Claro. Me fuerza estar aquí y sentirme como me siento. (Of course. It forces me to be here and feel the way I feel).

Since no further information is provided on the way he feels, I consider this utterance an illustration of concealed discourse. We can deduce the nature of his sensations, (dissatisfaction, pointlessness, frustration, oppression, fear) but we are not given any clues to choose among them. By using an evasive formula (the way I feel) which might be regarded as euphemistic, Jorge avoids an offensive description of his emixile status in Spain. According to Ruiz Ruiz, the insinuated and concealed dimensions reach the same goal in different ways: saying partially and not saying something, but both carried out intentionally.

2c. Me preocupo por los míos que están en Guinea. Primero porque están en Guinea y luego porque son Bubi. Y la situación es la que es. (I am worried 
about my relatives in Guinea. First because they are in Guinea and then because they are Bubi. And the situation is what it is).

There are at least two implicit meanings in this sentence: first, the insinuated dimension represented by the speaker's worries regarding (1) the oppressive regime in which his family lives and (2) their ethnic group (Bubi) that seems to suffer persecution by the group in power (Fang), see endnote 7. Secondly, a concealed dimension seems to underlie the sentence "the situation is what it is" which does not reveal any concrete data, but instead, leaves the interlocutor to imagine for him/herself. While the notions of "Guinea" and "Bubi" resort to the hearer's objective knowledge on both country and ethnic group, the euphemistic expression (is what it is) offers no clues by itself (except for the fact that semantically, its usage is traditionally associated to unsatisfactory rather than rewarding things). This perception is reinforced by researchers such as Ondo, Bokesa and Liniger-Goumaz or Okenve, who described the situation as "popular discontent silenced and fearful of reprisals". Instead of saying "the situation is unbearable/terrifying”, Jorge opts to hide information as a cautious form of criticising. This “discursive prudence” even in exile is a recurrent strategy used by my interviewees.

Rita

2d. [How would you describe current Guinean society?] [A sigh followed by silence] 'La sociedad guineana... qué bonito suena.' [silence for a while]. (Guinean society... sounds so good). Debería cambiar de mentalidad. Pensar en un futuro mejor para todos. No pensar tanto en nosotros mismos. (It should change its mentality. It should think of a better future for all. We shouldn't focus so much on ourselves).

Since my interviewee does not add any information to the sentence itself, we do not know 
whether her evasiveness refers to the fact that there is no such thing, but only the utopia of a Guinean society, or rather, she does not wish to define it as it is. In fact, Rita avoids strong criticism in her whole narration, and this concealed dimension is quite frequent in her discourse. From Brown and Levinson’s politeness theory perspective, silence is seen as an avoidance strategy (“Don’t do the FTA”) but Sifianou (67) shows that remaining silent can be facethreatening too as a manifestation of either negative, positive or off-record politeness (72). From the utterance coming after her significant silence, we deduce that she is not fond of current Guinean society which she criticizes. Unlike Jesús (who distanced himself from the Fang in power) Rita, who belongs to the Anabonese group, assumes the defects of the hypernym (Guinean society) switching to the plural "we/ourselves”.

The Failed Dimension (7 samples found in my corpus)

Related to the previous category, this dimension emerges precisely from a failed concealment strategy, since it concerns information unintentionally revealed and the speaker is, somehow, betrayed by his/her own words. This dimension is much less present in our interviewees’ narrations of themselves, but there are still some examples.

\section{Emilio}

3a. [Are there any problems with mixed couples?] En apariencia no hay problemas con las parejas mixtas, pero en el fondo, sí. El hombre guineano no quiere ser dominado. Y la mujer española tiene el don de mando. (Apparently, there are no problems with mixed couples, but actually there are. The Guinean man doesn't want to be dominated. And the Spanish woman has the gift of command).

In this case, the failed dimension is related to male-chauvinism. My interviewee (as a 
Guinean man - a category including his Ndowe ethnic group) does not want to be dominated while Spanish women want to dominate (the lexical choice is interesting in its ironical acceptation: the "gift" of command). Implicitly Spanish women are criticized and blamed for problems within couples. He reveals his sexism through a failed discourse.

3b. [What did your parents say about Spaniards?] 'En mi infancia, en casa no tenían ni esperanza, ni aspiraciones de independencia.’ [¿¿Y sobre los europeos?] No los criticaban porque no se veían. Eran marineros que bajaban del barco de noche y al día siguiente se iban. (In my childhood, my family had neither hope nor aspirations of independence. [And about Europeans?] They were not criticized as they were invisible, normally sailors who would disembark by night and sail off in the morning).

The implicit information refers to the sense of resignation of the Guineans at that time towards Spanish colonialism. However, in his answer, my interviewee does not say his family did not want a change, but only that a change was unlikely to happen. He thus avoids answering about his parents’ opinion on Spaniards. In turn, he introduces the notion of independence, therefore, Spaniards were seen mainly as colonialists/oppressors. A question formulated in general terms is answered in concrete terms. Independence is related to an interesting lexical choice distinguishing between "hope” and "aspiration”, in other words, neither fate nor human action could be trusted to put an end to colonial exploitation. I opted to include this example in the failed dimension on grounds of the information that is leaked by the speaker subsequently: “Europeans were not criticized as they were invisible”, hence the fact lacking in Emilio’s answer is "Spaniards were criticized by my parents and they were seen as oppressors". 
Juan

3c. Me relaciono por igual con todas las etnias [...] No tengo choques con mis amigos fang porque llevan mucho tiempo aquí y hablamos de cosas intrascendentes. Tengo más afinidad con los bubi y anoboneses. (I socialize equally with all ethnic groups. I do not have clashes with my Fang friends because they have lived here for a long time and we talk about trivial things. I have more affinity with the Bubi and Anabonese).

This is a very interesting example of failed discourse. In this answer, there are three utterances. In the first place, the question did not mention the Fang but the answer focuses directly on this group. Secondly, sentences (2) and (3) contradict sentence (1) by introducing the term "clash" and by seeking to argue that everything runs smoothly. The surprising revelation comes with the explanation which provides such categories as "time spent in Spain" (suggesting that in EG the relationship would be different) and conversational subjects (implying he and his Fang friends do not touch on sensitive issues). Finally, he realises his plea for friendship based on such premises is not entirely plausible and he admits he has more affinity with other groups. The Underlying Dimension (8 samples found in my corpus)

This dimension refers to the information the speaker releases implicitly although he/she intends to either do so or not do so. The strategy linked to this discourse is the use of conventional metaphors that tend to go unnoticed, generating underlying and implicit meanings. Jesús

4a. [Is the return to EG an option?] 'Guinea es tan rica que se puede vivir sin pegar clavo.' Hay más de 700,000 guineanos que mueren de hambre, matan, roban y la delincuencia ha subido. (Guinea is so rich that you can live there 
without lifting a finger. There are over 700,000 Guineans who starve or have to kill or rob and crime levels have risen).

The underlying meaning in this answer is given by a concessive adverbial subordinate: no matter how rich the country is, wealth is not distributed, and people live in poverty. My interviewee wishes neither to state this explicitly nor to hide it. The Spanish idiom no pegar ni clavo is based on a conventional metaphor. This utterance was preceded in the interview by another: [Why did you choose Spain?] Un guineano no se encuentra mejor en otro país que España; el dinero no lo es todo. (A Guinean is not better off in any country other than Spain; money is not everything).

I consider the last part of this message to be a sample of failed discourse since the interviewee does not refer anywhere else in his narration to the fact that his choice (Spain) is the least advantageous in economic terms, although he points at Brussels as a good business opportunity for him. He intends to give a positive image of Spain, but in his answer, he drops a hint at poverty which I would classify as an example of the failed dimension.

Rita

4b. Para construir Anobon, hay que ir a Anobon. (In order to build Anobon, one has to go to Anobon).

Although this underlying meaning is not structured on a metaphor, but on a stylistic repetition of a toponym, rather conspicuously conveying the strength of her point (the uselessness of opposition in exile), I consider it an example of the underlying dimension of discourse on the grounds of its criticism to those parties that do not seem to meet expectations or self-criticism/justification for not doing more because of the distance. 


\section{Emilio}

4c. En el barrio me llaman "el cubano". (In my neighbourhood, they call me "the Cuban”).

This answer to the question “Do you feel recognised in Spanish society as a Guinean?” might be regarded as an underlying dimension of discourse on grounds of this nickname, which encapsulates two semantic conditions of veracity (black and Spanish speaking) which are met by a Cuban as well as by an Equatoguinean. On the other hand, the implied information suggests Spaniards make such inferences due to a lack of knowledge (for instance linguistic: the accent is different) or disinterest. However, the nickname can be interpreted positively, since apparently, Cubans are not socially frowned upon in $\operatorname{Spain}^{9}$ or negatively, as a euphemistic way of calling him black and thus underlining his otherness.

\section{Viviana}

4d. [What do you think best describes the Guinean society?] Quizás es injusto lo que voy a decir. Es una sociedad que quiere occidentalizarse sin ser de occidente. (Perhaps it is unfair what I am about to say. Equatoguinean society wants to "westernalise" itself without belonging to the West).

This example of underlying dimension of implicitness (Viviana's diagnosis of the situation in EG) is based on a repetition (occidentalizar/occidente) which suggests (1) my interviewee's disillusionment with the betrayal of traditions and ancestors' values; and (2) a whole array of implicit meanings related to a country seeking to borrow western democratic values which are desirable as much as its African identity, but which belong to the oppressor in the past, which is now a business partner, especially since the discovery of oil. The implicit message is followed by an attenuation/explanation ("which is not bad, but it has made us lose 
part of what we are”) which can be interpreted as: (a) a courtesy strategy lest the host society who belongs to "occidente" should feel offended, and (b) a recognition of the advantages that westernalisation entails.

\section{Conclusions}

In this study ${ }^{10}$, I sought to detect indicators of implicitness in the self-narrations of six Equatoguinean emixiles in Spain (Alicante). The originality of this approach resides in the type of discourse tackled (social), scarcely investigated by researchers in discourse analysis so far, and in the very nature of the unresolved Equatoguinean issues, related to colonialism, African totalitarianism, economic interests and Western double standards. As a general observation, we could say that the implicit discourse elements encountered in these interviewees' narrations of their own life stories, appear both in their individual recollections and in their collective remarks and criticisms on home and host societies. Initially, my assumption was that the interviewees' choice of implicitness was related to exile and fear of reprisal. This is only partially true, since not all the illustrations of implicit discourse are related to a coercive political dimension. Together with fear, there are other motives for insinuating or concealing instead of making explicit statements: shared knowledge (e.g. orality, intrinsic to African cultures, is taken for granted by the interviewees), male supremacy (in spite of a matrilineal kinship) even male chauvinism, stereotypes and generalizations (some inherited from the colonial power about other ethnic groups) or politeness (FTA avoidance) in the case of criticisms to Spanish society (often performed with courtesy/humour/irony).

My hypothesis suggested that some of the dimensions of implicit discourse were more frequently used than others. Indeed, as I have showed, the two dimensions based on reluctance to explicitness, are the most representative in my corpus, with abundant examples (21 insinuated 
and 17 concealed samples). The underlying dimension (8 samples) and the failed dimension (7) are less present in my interviewees’ narrations which shows they are not undecided regarding whether or not to make a statement (underlying dimension). Neither are they betrayed by their own thoughts/words (failed dimension) since they are aware of what they wish to convey and have the linguistic means, sufficient time and trust in the interviewer to do so. If they choose not to, it is due to other reasons such as courtesy (towards Spanish society) or coercive measures exerted by the Equatoguinean authorities. Thus, they often opt for the insinuated and for the concealed dimensions in order to avoid explicit criticism of either home or host societies, while maintaining the truthfulness of their narrations, which is essential in their reconstruction of themselves as emixiles.

Another more general conclusion that can be drawn from this analysis is that discourse is resourceful enough to allow a speaker to hide or insinuate whenever (s)he cannot/does not want to be explicit and I hope to have brought to light some empirical data from the social background to support this idea. Obviously, the sample size does not allow us to extrapolate in quantitative terms, but the qualitative implications of this analysis may constitute a starting point for further study in such a scarcely visited field as implicitness in emixiles' social discourse, elsewhere or in other historical contexts and individual/collective circumstances. 


\section{Notes}

1. In their study on silence in social work dialogue, in which they analyse the narration of a social worker interviewed by a researcher on the topic of children's services in a public welfare organization, Hall, Sarangi and Slembrouck show that even those approaches regarding language as social action, "have paid insufficient attention to the occurrence of silent or silenced voices in a text, this way running the risk of silencing "silence" itself (182). Thus, linguistic analysis, they say (citing Birch), contributes to "cultural silencing if it ignores texts and discourse situations which, from a dominant cultural perspective, are uncomfortable”.

2. In the late sixties, only a fortunate few (chosen by their tribes or priests) could benefit from further education in the metropolis; nowadays scholarships in Spain are still awarded on the basis of lists imposed by the EG government, the alternative being family or church support.

3. The interview contains over 113 questions and it is structured in three sections dealing with:

(1) paternal and maternal family and childhood (25 questions); (2) youth and studies (15 questions); and (3) social networking and exile/migration (73 questions).

4. All the interviewees possess extensive family networks in Spain, as well as close relatives in Equatorial Guinea. For all of them Spain was the first and only migration destination.

5. Jesús, age 47, born in Ayene, arrival in Spain 1999, social class: low. Jorge, age 61, born in Basakato, arrival in Spain 1969, social class: middle. Rita, age 60, born in Annobon, arrival in Spain 1998, social class: low. Emilio, age 71, born in Corisco, arrival in Spain 1960, social class: low. Juan, age 67, born in Basakato, arrival in Spain 1966, social class: high. Viviana, age 49, born in Malabo, arrival in Spain 1982, social class: middle. 
6. It takes 10 years to be granted Spanish nationality according to article 22.1 of the Civil Code, but preferential treatment is given to former colonies (see Cea D'Ancona and Valles Martínez, Informe 2009 103).

7. All the samples (originally in Spanish) have been translated into English by the author.

8. According to Rodriguez Nuñez (35) "within the climate of terror and repression, ethnic minorities, especially Bubi who are majority in the Bioko Island, are persecuted and eliminated”.

9. Neither official report on the evolution of racism and xenophobia in Spain (Cea D'Ancona and Vallés Martínez, Informe 2009; Informe 2013) includes information on Cubans as a target group of these attitudes. Unlike Equatoguineans, who complain of discrimination, Cubans are mentioned in other immigrants' declarations in a positive light, as friendly figures.

10. This research was conducted within the HAR2011-22752 project, entitled "The Handling of Cultural Diversity and the Socio-political Influence of Transnational Migration in Two Former Spanish Colonies: Equatorial Guinea and Morocco”. 


\section{Works Cited}

Aixelà Cabré, Yolanda. Guinea Ecuatorial: ciudadanías y migraciones transnacionales en un contexto dictatorial africano. CEIBA, 2011.

---. “Equatorial Guinean Women’s Roles after Migration to Spain: Conflicts between Women’s Androcentric Socialization in Equatorial Guinea and Their Experiences after Migration.” Urban Anthropology and Studies of Cultural Systems and World Economic Development, vol. 42, no.1-2, 2013, pp. 1-55.

Asher, Nicholas. “Implicatures and Discourse Structure.” Lingua, vol. 132, 2013, pp. 13-28.

Asher, Nicholas, and Alex Lascarides. Logics of Conversation. Cambridge UP, 2003.

Campos Serrano, Alicia. "Petróleo y estado postcolonial: transformaciones de la economía política en Guinea Ecuatorial, 1995-2010. Implicaciones para la coherencia de las políticas españolas.” Avances de Investigación, vol. 54, 2011. Cealci Fundación Carolina, https://www.fundacioncarolina.es/wpcontent/uploads/2014/07/Avance_Investigacion_54.pdf.

Carston, Robyn. “Truth-Conditional Content and Conversational Implicature.” The Semantics/Pragmatics Distinction, edited by Claudia Bianchi, CSLI Publications, 2004, pp. 303-35.

Cea D’Ancona, María Ángeles, and Miguel S. Vallés Martínez. Evolución del racismo y la xenofobia en España, Informe 2009, Observatorio Español del Racismo y Xenofobia (OBERAXE), Ministerio de Trabajo e Inmigración, 2009.

. Evolución del racismo, la xenofobia y otras formas conexas de intolerancia en España. Informe 2013. Observatorio Español del Racismo y Xenofobia (OBERAXE), Ministerio de Trabajo e Inmigración, 2014. 
Denantes Teulade, Samuel. Malabo, le nouvel Eldorado pétrolier de l'Afrique. L'Harmattan, 2009.

Ducrot, Oswald. "Presupuestos y sobreentendidos (Revisión).” El Decir y lo dicho. Polifonía de la enunciación, translated by Irene Agoff, Paidós, 1977, pp. 35-48.

Escandell-Vidal, Victoria. “Understanding Implicit Meaning Understanding.” Verbal Communication, edited by Andrea Rocci and Louis de Saussure, Walter de Gruyter. 2016, pp. 97-121.

Hall, Christopher, et al. "Silent and Silenced Voices: Interactional Construction of Audience in Social Work Talk.” Silence: Interdisciplinary Perspectives, edited by Adam Jaworski, Mouton de Gruyter. 1997, pp. 181-212.

Horn, Laurence R. "Implicature”. The Handbook of Pragmatics, edited by Laurence R. Horn, and Gregory Ward, Blackwell, 2004, pp. 3-28.

Iliescu Gheorghiu, Catalina and Rita Bosaho. “Guinea Ecuatorial: una propuesta de análisis discursive de los silencios impuestos.” Tras las huellas del colonialismo español en Marruecos y Guinea Ecuatorial, edited by Yolanda Aixelà, Consejo Superior de Investigaciones Científicas, 2015, pp. 195-220.

Irmer, Matthias. Bridging Inferences: Constraining and Resolving Underspecification in Discourse. Interpretation. Language, Context and Cognition Series, Walter de Gruyter, 2011.

Jaworski, Adam, editor. Silence: Interdisciplinary Perspectives, Mouton de Gruyter, 1977.

Kisielewska-Krysiuk, Marta. "Lying and the Relevance-Theory Explicit-Implicit Distinction.” Anglica, An International Journal of English Studies, vol. 25, no. 2, 2016, pp. 73-86. CEJSH, http://cejsh.icm.edu.pl/cejsh/element/bwmeta1.element.desklight-5a8257fc- 
357b-4173-a035-13dff0b28fc6/c/Anglica_25-2_073-086_MKisielewska-

Krysiuk_Lying.pdf

Ki-Zerbo, Joseph. Historia del África negra. De los orígenes a las independencias, Bellaterra, 2011.

Levinson, Stephen C. Presumptive Meanings: The Theory of Generalized Conversational Implicature. Cambridge, MIT Press, 2000.

Liniger-Goumaz, Max. De la Guinée Equatoriale. Eléments pour le dossier de l'Afro-fascisme. Geneva: Editions du Temps, 1983.

Ndongo-Bidyogo, Donato. Historia y tragedia de Guinea Ecuatorial. Cambio, 1977.

Okenve, Enrique Nzang. "Wa Kobo Abe, Wa Kobo Politik: Three Decades of Social Paralysis and Political Immobility in Equatorial Guinea.” Afro-Hispanic Review, vol. 28, no.2, 2009, pp. 143-62.

Ondo Ayang, Luís, Anacleto Bokesa Camó, and Max Liniger-Goumaz. 'Misceláneas Guineoecuatorianas II’. Nguemnismo: 33 años de auto-golpes y torturas. Corrupción nacional e internacional. Guinea Ecuatorial Cultural. Tiempos Próximos, 2002.

Recanati, François. Literal Meaning. Cambridge UP, 2004.

Rodríguez Núñez, Álvaro. “La antigua Guinea española: análisis y perspectivas.” Seminario del Centro Superior de Estudios de la Defensa Nacional (CESEDEN). Universidad de Santiago de Compostela, 2005. Cruz Melchor Eya Nchama, http://www.cmeyanchama.com/Documents/Guinee/trabajoceseden_Seminario.pdf Ruiz Ruiz, Jorge. “El discurso implícito: aportaciones para un análisis sociológico. Implicit Discourse: Contributions to a Sociological Analysis.” Revista Española de Investigaciones Sociológicas, vol. 146, 2014, pp. 171-90. 
Sifianou. Maria. "Silence and Politeness.” Silence: Interdisciplinary Perspectives, edited by Adam Jaworski, Mouton de Gruyter. 1977, pp. 63-84.

Ugarte, Michael. Africans in Europe. The Culture of Exile and Emigration from Equatorial Guinea to Spain. Illinois UP, 2010.

Van Dijk, Teun A. "Discurso y manipulación: discusión teórica y algunas aplicaciones.” Signos, vol. 39, no. 60, 2006, pp. 49-74.

Vertovec, Steven. Transnationalism. Routledge, 2009.

White, Peter R. R. “Appraisal.” Discursive Pragmatics, edited by Jan Zienkowski, et al., John Benjamins, 2011, pp. 14-36.

Wodak, Ruth. "Pragmatics and Critical Discourse. A Cross-Disciplinary Inquiry.” Pragmatics \& Cognition, vol. 15, no. 1, 2007, pp. 203-25. 